\title{
Lactuca tatarica (Asteraceae) in embryonic dunes on Wolin Island (NW Poland)
}

\author{
Wojciech Kowalski W. A. ${ }^{1}$, Andrzej Łysko² \& Agnieszka Popiela ${ }^{3 *}$
}

${ }^{1}$ Department of Botany and Nature Protection, Western Pomerania University of Technology in Szczecin, Słowackiego 17, 71-434 Szczecin, Poland

${ }^{2}$ Department of Environmental Protection and Management, Western Pomerania University of Technology in Szczecin, Słowackiego 17, 71-434 Szczecin, Poland

${ }^{3}$ Department of Botany and Nature Conservation, University of Szczecin, Felczaka 3c, 71-412 Szczecin, Poland

* corresponding author (e-mail: popiela@univ.szczecin.pl)

\begin{abstract}
By the end of the 19th century, Lactuca tatarica was reported for the first time from an adventive occurrence on the North Sea and Baltic Sea coasts. In Wolin Island, the species has become established in the natural habitat and is clearly spreading in recent years. The community with L. tatarica was studied currently on the western point of Wolin Island along the stretch between the mouth of the Swina (Swine) River and a newly constructed breakwater of the external harbour. The taxon occupies relatively low parts of the sandy elevations of dune ridges, in patches of the Honckenyo-Agropyretum juncei association (habitat 2110). Furthermore, L. tatarica has been reported in recent years from some locations in Świnoujście (Usedom (Uznam) Island), Międzyzdroje, Wisełka and Międzywodzie.
\end{abstract}

Key words: Honckenyo-Agropyretum juncei, distribution, Baltic Sea coast, neophyte, embryonic shifting dunes, habitat 2110

\section{Introduction}

Lactuca tatarica (L.) C.A. Mey. (Sonchus tataricus L., Mulgedium tataricum (L.) DC.) is an Asian-Southeastern European plant, also reported from adventive occurrences in Northwest and Central Europe (Feráková 1977; Lebeda et al. 2001). It belongs to the OrientalTuranian floristic elements of flora. Its geographical range includes the area of the Caucasus and the Iranian Plateau, southern Siberia (reaching to the east to the Lena River), as well as Central Asia (to the Pamir Mountains) and China and Tibet (Hultén \& Fries 1986). In Europe, it is a native species in Bulgaria, Romania, Russia and Ukraine (Feráková 1977; Jehlik 1980). The taxon is characteristic for steppe vegetation in southeastern Europe, from Volhynia (W Ukraine) to the western coasts of the Black Sea and the Bosporus. It can be found on the banks of water reservoirs and running waters, on sandy and clayey soils, also on seashores, mainly at saline locations, as well as in fields where it is sometimes a troublesome weed (e.g. Golub et al. 1995; Wucherer et al. 2001; Kravchenko et al. 2004;
Tzonev et al. 2005; Ajmal Khan \& Qaiser 2006; Bano \& Qaiser 2011; Făgăra 2013).

By the end of the 19th century, L. tatarica was reported for the first time from an adventive occurrence on the North Sea and Baltic Sea coasts, in Germany and Great Britain (Knapp \& Jage 1978) and, then, from inland locations, mainly ruderal ones in many sites in Central and Northern Europe (Feráková 1977; Knapp \& Jage 1978; Jehlik 1980). On the Baltic Sea coasts, the first location of L. tatarica was reported on Rügen (Rugia) Island. The Pallas's sandgrouse (Syrrhaptes paradoxus), seen in Europe in the late 19th century and the early 20th century, is presumed to be responsible for its introduction (Jehlik 1980; Hordowski 2014). For the first time, L. tatarica was found in 1902 near Thiessow, i.e. a dozen or so years after the greatest invasion of the Pallas's sandgrouse, and these birds were repeatedly seen on the island where they were nesting (Preuss 1909; Kovanda 1958; Hordowski 2014). Occurrences of L. tatarica on the North Sea and Baltic Sea coasts could be also associated with maritime transport (ballast) (König 2005, and the literature cited there). 
Leick (1926) reported that, in 1921, the geographical range of this taxon included the south-eastern coast of Rügen (Rugia) Island and the coast of the Greifswalder Bodden. Hegi (1929) determined the eastern limit of L. tatarica range of occurrence to be the mouth of Peene (Piana) River. Its occurrence on the coasts of Usedom (Uznam) Island was confirmed by Holzfuss (1937). According to Jäger \& Werner (2005), the Baltic range of this taxon in Mecklenburg is limited to the coasts of the Greifswalder Bodden and Usedom (Uznam), Rügen (Rugia) and Hiddensee Islands. The problem of L. tatarica spreading dynamics in the area of Baltic coasts of Mecklenburg-Vorpommern and in the north-eastern Germany was studied by numerous authors (Fukarek 1969, 1989; Krisch 1990; Burke \& Grime 1996; Grosholz 2002; Litterski \& Berg 2000; Kowarik 2003; König 2005; Berg \& Barth 2008). Detailed information on this species was collected in a floristic database and herbarium collection of the University of Greifswald (AG Geobotanik MV. 2005).

Kovanda (1958) and Urbański (1958) gave the first information referring to the occurrence of $L$. tatarica on the Polish coast from Międzyzdroje and the western part of Świnoujście. The latter author did not report the occurrence of this taxon on Wolin Island despite his explorations, both along the Szczecin Lagoon (Stettiner Haff) and along the sea section stretching from Przytor to Międzywodzie. Piotrowska (1966) found the species under discussion at two locations in Świnoujście, one at the state border and another at a breakwater. Misiewicz (1976) confirmed the first one and found another one on the right bank of the Swina (Swine) River in the area around a harbour construction site (current ferry terminal).

This study aimed at documenting a plant community with $L$. tatarica at a location in Świnoujście-Warszów on
Wolin Island and presenting a temporary map of its distribution in the western part of the Polish Baltic coast.

\section{Material and methods}

The occurrence of L. tatarica on the coast of the east part of the Świna (Swine) River was observed in 2011 and then in 2012-2014 during the monitoring surveys of natural habitats conducted by the first author (WK) in connection with the construction of LNG (Liquefied Natural Gas) terminal. On 28/07/2014, five phytosociological relevés were made by the Braun-Blanquet method. Chemical analyses of basic parameters of sandy soil, i.e. salinity and nitrogen, phosphorus and potassium contents were measured in Regional Agrochemical Station in Szczecin using standard methods. The herbarium material was deposited at the Herbarium Stetinensis of the University of Szczecin. The map of L. tatarica distribution on the Western Pomeranian seashore was made, based on a database of the Western Pomeranian Atlas of Distribution of Vascular Plants and Fungi (ZARRiG), using the cartogram method, with a basic unit of 2.5 x $2.5 \mathrm{~km}$ (Popiela et al. 2013a, 2013b, see also: http://212.14.14.38/zarrig/zarrig_www/).

\section{Results}

\subsection{Distribution of Lactuca tatarica in the western part of Polish Baltic coast}

L. tatarica is found in the Polish part of Usedom (Uznam) Island and on Wolin Island (Fig. 1). Its locations are concentrated along the Baltic coast on white dunes. So far, its occurrences in the central part of the Wolin Island seashore (i.e. between Międzyzdroje and Wisełka - with a cliffy coastline) have not been re-

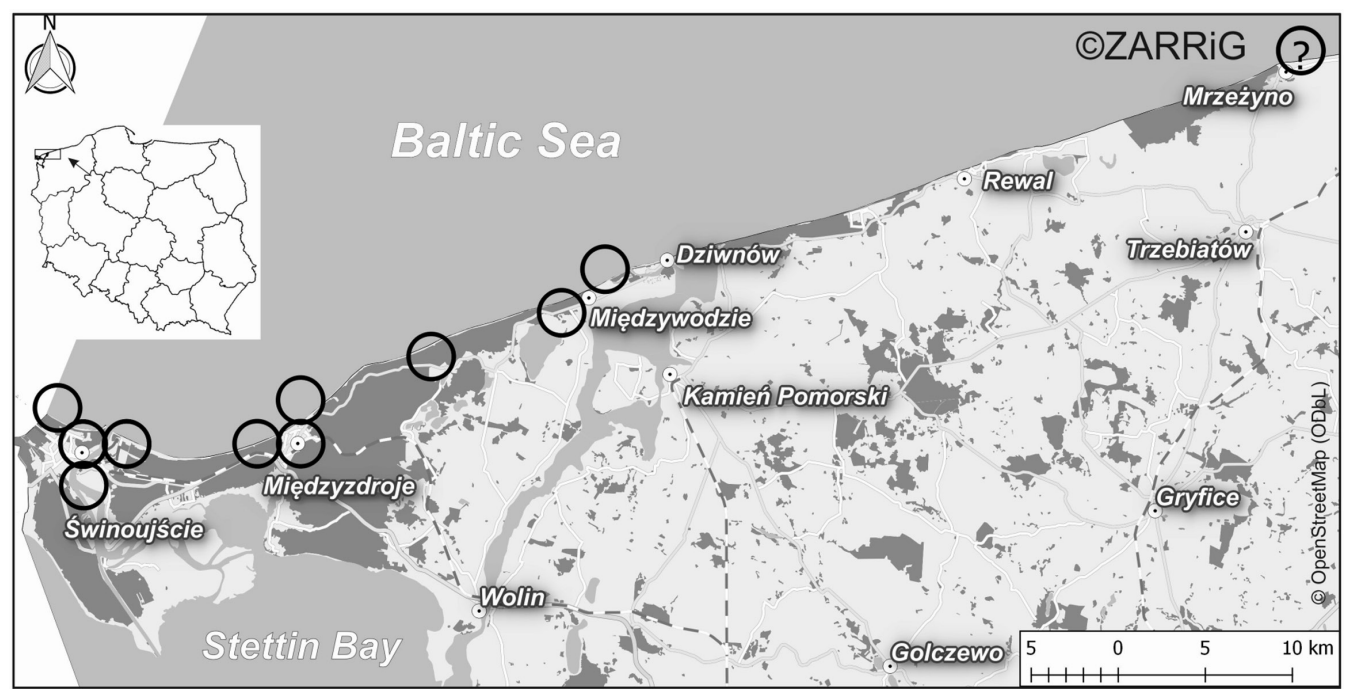

Fig. 1. Distribution of Lactuca tatarica in the western part of the Polish Baltic Sea coast 
ported. In 2011-2014, blue lettuce was reported from a few locations in Świnoujście-Warszów, near the LNG terminal construction site. It was not found to the east of external harbour breakwater along the section of about $1.5 \mathrm{~km}$. Furthermore, this taxon has been recorded in recent years from some locations in Świnoujście (Usedom (Uznam) Island), Międzyzdroje, Wisełka and Międzywodzie. In the ATPOL database, there is also a floristic datum from Mrzeżyno given by E. Ćwikliński in 1973. Because this datum has not been published and a herbarium specimen is not available, this location is marked on the map as a presumptive one.

\subsection{Association Honckenyo-Agropyretum juncei with} Lactuca tatarica at a Świnoujście-Warszów location

The community was found on the western point of Wolin Island along the stretch between the mouth of the Świna (Swine) River and a newly constructed breakwater of the external harbour (Fig. 2). Single specimens of L. tatarica were observed for the first time in this area in 2011, whereas in 2014 five large patches were localised over a distance of $250 \mathrm{~m}$. They were all located in the formation zone of the initial stages of coastal sand dunes, outside the area of winter storm surge impact. Patches with $L$. tatarica occupy relatively low parts of the sandy elevations of dune ridges, formed by the aeolian processes (Fig. 3). They are loose, fine-grained sands initially deposited by sea waves on the sea shore and moved to the upper parts of the beach by wind. Their specific feature is their salinity reaching the value in the range of $0.08-0.14 \mathrm{~g} \cdot \mathrm{dcm}^{3}$, with total nitrogen content

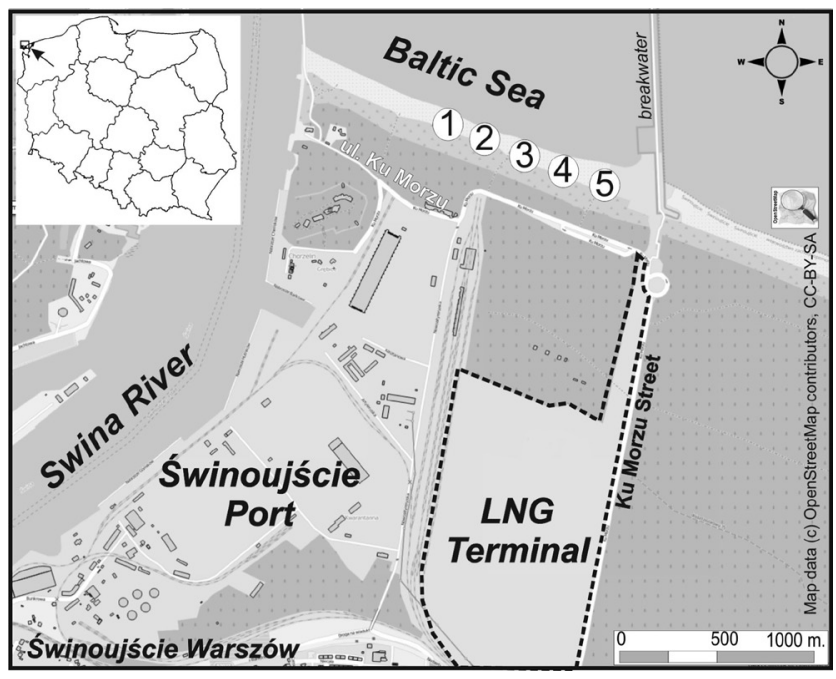

Fig. 2. Occurrence of populations of Lactuca tatarica near LNG terminal, Świnoujście-Warszów

Explanations: 1, 2, 3, 4, 5- localities of relevés

of $0.3-0.9 \mathrm{mg} \cdot \mathrm{dcm}^{3}$, and phosphorus and potassium concentrations of $11.0 \mathrm{mg} \cdot \mathrm{dcm}^{3}$ and $7.0-14.0 \mathrm{mg} \cdot \mathrm{dcm}^{3}$.

The plant association favouring the spread and migration of $L$. tatarica includes different developmental forms of the Honckenyo-Agropyretum juncei R.Tx. 1955 of the Ammophiletea Br.-Bl. et R.Tx. 1943 class (Fig. 4). Characteristic species are: Honckeya peploides and Elymus farctus subsp. boreoatlanticus, a rare species in the Polish flora found on the Wolin Island only (Wróbel \& Banaś-Stankiewicz 2015, Wróbel \& Kowalski

Table 1. Honckenyo-Agropyretum juncei with Lactuca tatarica in Świnoujście-Warszów (Wolin Island)

\begin{tabular}{|c|c|c|c|c|c|}
\hline Successive number of relevé & 1 & 2 & 3 & 4 & 5 \\
\hline Date: Day/Month/Year & \multicolumn{5}{|c|}{ 28.07.2014 } \\
\hline Area of relevé $\left[\mathrm{m}^{2}\right]$ & 25 & 20 & 25 & 24 & 26 \\
\hline Cover of layer c [\%] & 55 & 50 & 35 & 30 & 55 \\
\hline Number of species in relevé & 6 & 9 & 6 & 7 & 7 \\
\hline \multicolumn{6}{|l|}{ Ch. Ass. Honckenyo-Agropyretum juncei } \\
\hline Elymus farctus subsp. boreoatlanticus & 1.2 & . & 2.2 & 1.2 & 2.3 \\
\hline Honckenya peploides & 2.2 & 3.2 & 2.3 & + & + \\
\hline \multicolumn{6}{|l|}{ Ch. All. Agropyro-Honckenyion peploidis } \\
\hline Ammophila arenaria & 2.2 & 1.2 & 1.2 & + & . \\
\hline Ammocalamagrostis baltica & + & + & . & . & + \\
\hline Festuca rubra var. arenaria & + & + & + & + & 1.1 \\
\hline \multicolumn{6}{|l|}{ Ch. Cl., O. Ammophiletea } \\
\hline Leymus arenarius & . & 2.1 & . & 1.2 & 1.2 \\
\hline \multicolumn{6}{|l|}{ Other } \\
\hline Lactuca tatarica & 3.3 & 2.2 & 1.2 & 3.3 & 3.3 \\
\hline Hieracium umbellatum ssp. dunense & . & 1.1 & + & . & . \\
\hline Chondrilla juncea & . & + & . & . & + \\
\hline Conyza canadensis & . & + & . & . & . \\
\hline Salsola kali ssp. kali & . & . & . & + & e \\
\hline
\end{tabular}




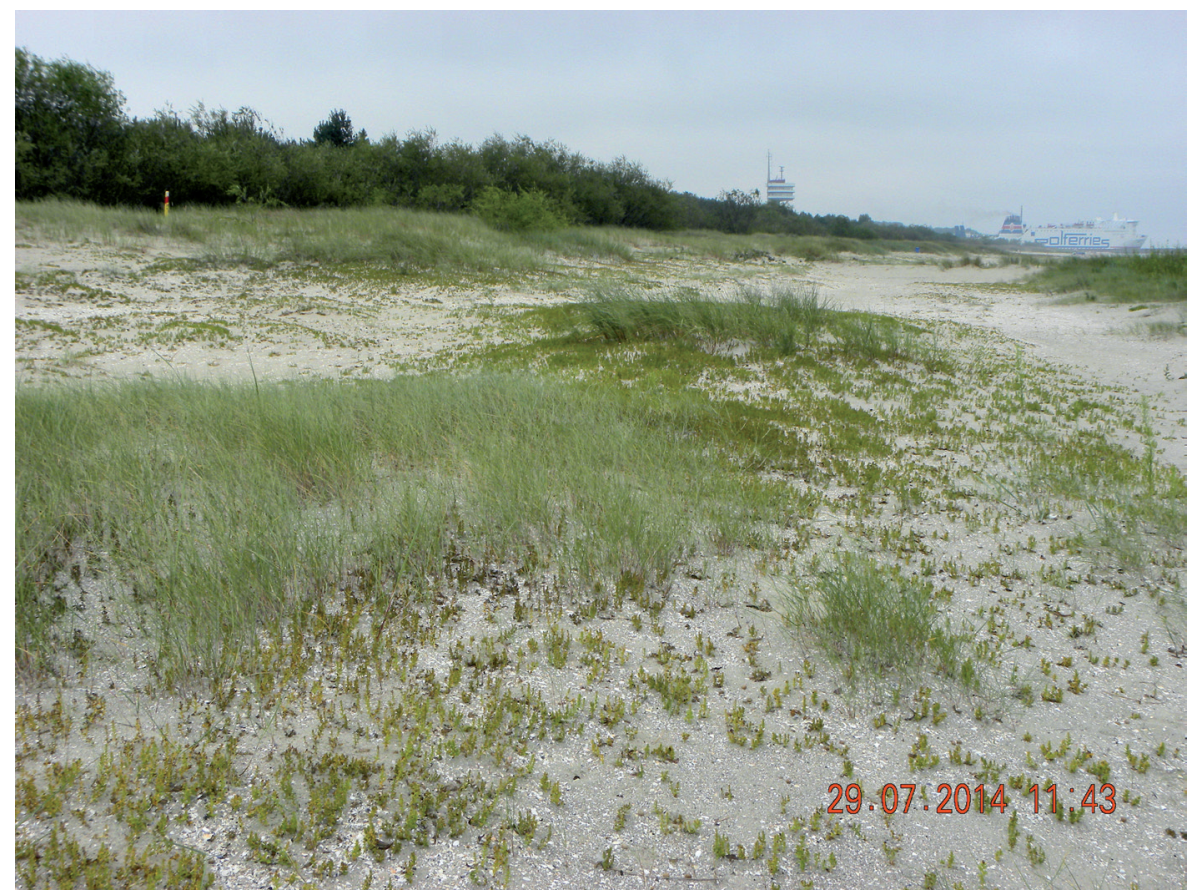

Fig. 3. Costal dunes with Lactuca tatarica in Świnoujście- Warszów

2015). Our Honckenyo-Agropyretum juncei relevés show a vascular plant species number of $7 \pm 1.22$ with plot size of $24 \mathrm{~m}^{2} \pm 2.34 \mathrm{~m}^{2}$. The cover values fluctuate at about $45 \% \pm 11.7 \%$ (mean data from Table 1 with given standard deviation, $\mathrm{n}=5$ ). The participation of L. tatarica in the studied patches is 10 to $50 \%$ with, 10 to 20 specimens on $1 \mathrm{~m}^{2}$ area. In most patches, young plants in early developmental stages predominate. The salinity level of beach sands is generally very variable, which results from high movement dynamics of $\mathrm{Na}^{+}$ ions. The sodium salts are delivered and accumulated by sea water flooding the beach or come out with the wind-blown sand, or are washed away by precipitation. The content of total nitrogen, phosphorus and potassium should be regarded as trace amounts.

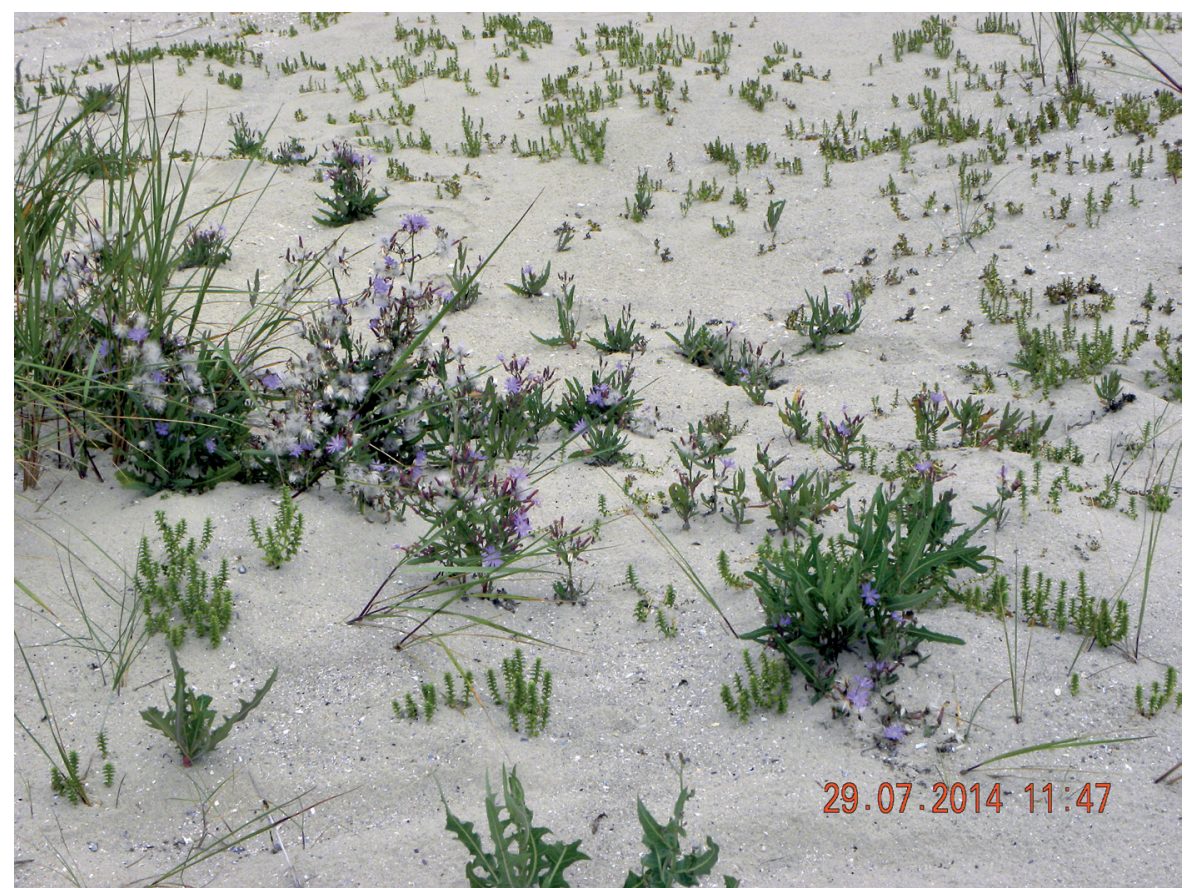

Fig. 4. Honckenyo-Agropyretum juncei with Lactuca tatarica at Świnoujście-Warszów location 


\section{Discussion}

Lactuca tatarica in Wolin Island is a species naturalised in the natural habitat and clearly spreading in recent years. Patches of the Honckenyo-Agropyretum juncei association, where this species is found, are rather poor in terms of flora. The salinity of habitats studied as well as values of other basic chemical parameters are characteristic for fine-grained beach and dune sands. $L$. $t a-$ tarica is found in adventive occurrences on the southern Baltic seashore also in the north-eastern Germany and Lithuania and Latvia (Ploompuu 1997; Litterski \& Berg 2000; Laime 2013). In Germany, around Greifswald and on Rügen (Rugia) Island, L. tatarica is commonly found both on initial dunes and in dense communities of the Ammophiletea and Koelerio-Corynophoretea classes on white and grey dunes, as well as in coastal halophilous communities of the Cakiletea maritimae class (Litterski \& Berg 2000; Berg et al. 2001; König 2005), as well as the authors' own observations on Rügen (Rugia) Island in 2014). In Latvia and Lithuania, L. tatarica was reported on single beaches and gravel lagoon shores in the initial associations of the Ammophiletea and Cakiletea maritimae classes and on coastal halophilous meadows (Ploompuu 1997; Rove 2013). It follows from the above that habitats where $L$. tatarica is found in Świnoujście are typical for this species in terms of its adventive, coast range in Central Europe and it is possible that it increases its populations. It is also possible that, in the future, the species will enter communities other than those of the Ammophiletea class (e.g. on grey dunes). In Poland, L. tatarica has a status of a taxon established at synanthropic locations (Tokarska-Guzik et al. 2012). Among countries in the Baltic Sea basin, it is treated as an "established" species in Germany and Latvia, whereas as an "invasive" or "potentially invasive" one in Estonia, Lithuania and Sweden (according to DAISIE and NOBANIS). Open habitats, poor plant density and, consequently, lack of competitive species facilitate the entry of $L$. tatarica into natural communities and its vegetative spreading via stolon runners (Ploompuu 1997; Rove 2013). In northeastern Germany, in the immediate vicinity to the Polish border, this species increases the number of its locations along the seashore; however, no evidence of threat to the native dune vegetation was found (Litterski \& Berg 2000; Berg \& Barth 2008). In view of the foregoing, the status of known coastal populations in Poland should be monitored, especially since L. tatarica was found in the initial stages of dune formation (habitat 2110) under legal protection (see also Popiela et al. 2015).

Acknowledgements. Authors wish to express their gratitude to the editors of the Atlas of Vascular Plants Distribution in Poland - Prof. Dr. Maria Zając and Prof. Dr. Adam Zając for access to the ATPOL database, and to Dr. Krzysztof Ziarnek for unpublished floristic data.

\section{References}

AG Geobotanik MV. 2005. Floristische Datenbanken und Herbarien Mecklenburg-Vorpommern. http://geobot. botanik.uni-greifswald. de/sammlungen/

AjMal Khan M. \& QAiser M. 2006. Halophytes of Pakistan: characteristics, distribution and potential economic usages. Sabkha Ecosystems. Taks for Vegetation Science 42: 129-153.

BANO R. \& QAiser M. 2011. A taxonomic revision of the genus Lactuca L. (Cichorieae- Asteraceae) from Pakistan and Kashmir. Pak. J. Bot. 43(5): 2259-2268.

Berg C. \& Barth H. 2008. Does the inner Baltic Sea coast provide a habitat for invasive neophytes? In: W. RABITSCH, W. F. Essl \& F. Kuingenstein (eds.). Biological Invasions - from Ecology to Conservation. Neobiota 7: 218-223.

Berg C., Dengler J. \& Abdank A. (eds.). 2001. Die Pflanzengesellschaften Mecklenburg-Vorpommerns und ihre Gefährdung - Tabellenband. Herausgegeben vom Lan desamt für Umwelt, Naturschutz und Geologie Mecklenburg-Vorpommern. Weisdorn Verlag, Jena.

Burke M. J. W. \& Grime J. P. 1996. An Experimental Study of Plant Community Invasibility. Ecology 77: 776-790.

DAISIE European Invasive Alien Species Gateway, 2015. Lactuca tatarica. Available from: http://www.europe-
aliens.org/speciesFactsheet.do?speciesId=23192 [Accessed 16 st February 2015].

FĂGĂRA M. 2013. Habitats with conservation significance and psammophilous plant associations from Sulina Beach (Danube Delta Biosphere Reserve). Analele Ştiințifice ale Universității “Al. I. Cuza” Iaşi s. II a. Biologie vegetală 59(2): 85-98.

FERÁKOVÁ V. 1977. The genus Lactuca L. in Europe. 67-68 pp. Univerzita Komenského, Bratislava, Czechoslovakia.

FUKAREK F. 1969. Ein Beitrag zur potentiellen natürlichen Vegetation in Mecklenburg. Mitt. Florist.-Soziol. Arbeitsgem. N.F. 14: 231-237.

FukareK F. 1989. Ein Beitrag zur Einbürgerung von Neophyten in Mecklenburg. Archiv Freunde Naturgesch. Meckl. 29: 6-15.

Golub V. B., Togliatti \& Tchorbadze N. B. 1995. Vegetation communities of western substeppe ilmens of the Volga delta. Phytocoenologia 25(4): 449-466.

Grosholz E. 2002. Ecological and evolutionary consequences of coastal invasions. Trends in Ecology \& Evolution 17(1): 22-27.Hegi 1929.

Hegi G. 1929. Illustrierte Flora von Mittel-Europa. 1386 pp. München, J. F. Lehmanns Verlag. 
Holzfuss E. 1937. Beitrag zur Adventivflora von Pommern. Abh. u. Berichte d. Pommerschen Naturf. Ges. U. des Naturkundemuseums der Stadt Stettin. Dohrniana 16: 94-130.

Hordowski J. 2014. Występowanie pustynnika Syrrhaptes paradoxus w Polsce. Ornis Polonica 55: 1-21.

Holzfuss E. 1937. Beitrag zur Adventivflora von Pommern. Abh. u. Berichte d. Pommerschen Naturf. Ges. U. des Naturkundemuseums der Stadt Stettin. Dohrniana 16: 94-130.

HultéN E. \& Fries M. 1986. Atlas of North European Vascular Plants. North of the Tropic of Cancer. I. Introduction, taxonomic index to the maps 1-996. Maps 1-996. xvi+498 pp. Koeltz Scientific Books, Königstein.

JäGer E. J. \& Werner K. (eds.) 2005. Rothmaler W. (Begr.). Exkursionsflora von Deutschland. Bd. 4: Gefäßpflanzen: Kritischer Band. 10. völlig neu bearb. Aufl. 980 pp. Elsevier (Spektrum) München.

JEHLIK V. 1980: Distribution of Lactuca tatarica in Czechoslovakia and remarks on its occurrence. Preslia 52(3): 209-216.

KNAPP H. D. \& JAGE H. 1978. Zur Ausbreitungsgeschichte von Lactuca tatarica (L.) C. A. Meyer in Mitteleuropa. Feddes Repertorium 89(7-8): 453-474.KÖNIG P. 2005: Floren- und Landschaftswande1 von Greifswald und Umgebung. 629 pp. Weissdorn-Verlag Jena.

Kovanda M. 1958. Lactuca tatrica (L.) C.A. Meyer na Pomorzu Zachodnim. Fragm. Flor. Geobot. 4(1-2): 9-131.

KowARIK I. 2003. Biologische Invasionen. Neophyten und Neozoen in Mitteleuropa. 380 pp. Ulmer, Stuttgart.

Kravchenko O. E., Budrevskaya I. A. \& Luneva N. N. 2004. Lactuca tatarica. In: A. N. Afonin, S. L. Greene, N. I. Dzyubenko \& A. N. Frolov (eds.). Interactive Agricultural Ecological Atlas of Russia and Neighboring Countries. Economic Plants and their Diseases, Pests and Weeds [Online]. Available at: http://www.agroatlas. $\mathrm{ru} / \mathrm{en} /$ content/related/Lonicera_edulis/ [Accessed 18 st February 2015].

KRISCH H. 1990. Ökologisch-soziologische Artengruppen und Pflanzengesellschaften im Geolitoral der Boddenküste (Ostsee). Phytocoenologia 19: 1-28.

Laime B. 2013. 1210, Annual vegetation of drift lines. In: A. Auniñš (ed.). European Union Protected Habitats in Latvia. Interpretation Manual. Latvian Fund for Nature, Ministry of Environ mental Protection and Regional Development, Riga.

LebedA A., DoležAlová I., KřístKová E. \& Mieslerová B. 2001. Biodiversity and ecogeography of wild Lactuca spp. in some European countries. Genetic resources and Crop Evolution 48(2): 153-164.

Leick E. 1926. Die Pflanzendecke der Provinz Pommern. Pommerschen Heimatsbuch. Berlin.

Litterski B. \& Berg C. 2000. Naturräumliche Bindung und Einbürgerung von Neophyten in MecklenburgVorpommern. Gleditschia 28: 47-63.

Misiewicz J. 1976. Flora synantropijna i zbiorowiska ruderalne polskich portów morskich. Wyższa Szkoła Pedagogiczna, Słupsk.
NOBANIS - Invasive Alien Species Fact Sheet - Pseudorasbora parva. Available fr: http://www.nobanis.org/ speciesInfo.asp?taxaID=847 Accessed 16 st February 2015].

Ploompuu T. 1997. Lactuca tatarica - forming new part of the area by vegetative spreading - on northern coasts of Baltic sea. Botanica Lithuanica 1997(Suppl. 1): 125-127.

Piotrowska H. 1966. Rośliny naczyniowe wysp Wolina i południowo-wschodniego Uznamu PTPN, Prace Kom. Biol. 30: 1-283.

Popiela A., Łysko A. \& Wieczorek A. 2013a. Western Pomeranian Atlas of Distribution of Vascular Plants and Fungi (ZARRiG) - project scope and method. Plant Diversity and Evolution 130(3-4): 265-271.

Popiela A., Łysko A. \& Wieczorek A. 2013b. Zachodniopomorski Atlas Rozmieszczenia Roślin Naczyniowych i Grzybów (ZARRiG) - Zakres i Metoda Projektu. In: M. Kuzn M. \& A. Nienartowicz (eds.). Systemy informacji geograficznej w zarządzaniu obszarami chronionymi - od teorii do praktyki. Wyd. UMK, Torun.

Popiela A., Łysko A., Sotek Z. \& Ziarnek K. 2015. Preliminary results of studies on the distribution of invasive alien vascular plant species occurring in semi-natural and natural habitats in NW Poland. Biodiv. Res. Conserv. 37: 21-35.

Preuss H. 1909. Mulgedium tataricum (L.) DC. in Deutschland. Ber. Deutsch. Bot. Ges. 27(10): 566-568.

Rove I. 2013. Marine and coastal halophytic (brackish) habitats and coastal halophytic (brackish) habitats. In: A. Aunișš (ed.). European Union Protected Habitats in Latvia. Interpretation Manual. Latvian Fund for Nature, Ministry of Environmental Protection and Regional Development, Riga.

TokarsKa-GuZiK B., DAjdok Z., Zając A., Zając M., URBisz Al., Danielewicz W. \& HoŁdyński C. 2012. Rośliny obcego pochodzenia w Polsce ze szczególnym uwzględnieniem gatunków inwazyjnych. 197 pp. Generalna Dyrekcja Ochrony Środowiska, Warszawa.

Tzonev R., Dimitrov M. \& Roussakova V. 2005. Dune vegetation of the Bulgarian Black Sea Coast. Hacquetia 4(1): 7-32.

UrbaŃSKi J. 1958. Sałata tatarska Lactuca tatarica (L.) C.A. Meyer koło Świnoujścia. Bad. Fizjogr. Pol. Zach. 4: 241-245.

WróBel M. \& BANAŚ-STANKIEWICZ U. 2015. Rozprzestrzenienie perzu sitowego Elymus farctus w płatach zespołu Honckenyo-Agropyretum juncie na Mierzei Przytorskiej (obszar Natura 2000 „Wolin i Uznam” PLH 320019). Folia Pomer. Univ. Technol. Stetin., Ser. Agric., Aliment., Pisc., Zootech 307(24), in print.

Wucherer W., Breckle S.-W. \& Dimeyeva L. 2001. Flora of the Dry Sea Floor of the Aral Sea. In: S.-W. BRECKLE, M. Veste \& W. Wucherer (eds.). Sustainable Land Use in Deserts, 38-51 pp. Springer Verlag BerlinHeidelberg. 